\title{
PELAKSANAAN PELATIHAN BHD PADA MASYARAKAT DI DESA KARANG BAYAN KECAMATAN LINGSAR KABUPATEN LOMBOK BARAT
}

\author{
Hadi Kusuma Atmaja \\ Jurusan Keperawatan, Poltekkes Kemenkes Mataram, Indonesia
}

\section{Genesis Naskah:}

\begin{abstract}
Abstrak
Kasus-kasus penyebab terjadinya henti jantung dan henti napas dapat terjadi kapan saja, dimana saja dan pada siapa saja. Setiap orang dapat menjadi penolong pada korban yang tiba-tiba mengalami henti jantung. Penyelamatan ini akan sangat bermanfaat jika dilakukan sesegera mungkin dan sebaik mungkin. Setelah pelaksanaan pengabdian masyarakat ini diharapkan masyarakat mengerti dan mampu melaksanakan cara memberikan Bantuan Hidup Dasar Pada Masyarakat Di Desa Karang Bayan. Metode yang digunakan adalah ceramah, diskusi, tanya jawab, dan simulasi cara melakukan Bantuan Hidup Dasar (BHD) dalam upaya peningkatan kemampuan dan keterampilan dalam melakukan Bantuan Hidup Dasar (BHD). Pengabdian masyarakat ini dihadiri oleh masyarakat sejumlah 20 Orang. Dalam kegiatan ini masyarakat sangat antusias dan aktif dalam mengikuti pelatihan. Masyarakat mampu menyebutkan tanda dan gejala seseorang yang membutuhkan pertolongan Bantuan Hidup Dasar (BHD dan mampu melaksanakan cara pemberian pertolongan Bantuan Hidup Dasar (BHD)
\end{abstract}

Kata Kunci: Pelatihan; Bantuan Hidup Dasar; Masyarakat

\section{IMPLEMENTATION OF BASIC LIFE SUPPORT (BLS) TRAINING TO THE COMMUNITY IN KARANG BAYAN LINGSAR LOMBOK BARAT}

\begin{abstract}
Cases the cardiac arrest and respiratory arrest can occur anytime, anywhere and to anyone. Everyone can be a helper when the victim suddenly arrives at cardiac arrest. This rescue will be very useful if done as soon as possible and possible. After carrying out this community service, community are expected to understand and be able to seek Basic Life Support in the Karang Bayan. The methods used are lectures, discussions, questions and answers, and simulations of how to do Basic Life Support (BLS) in an effort to support the improvement of abilities and skills in conducting Basic Life Support (BLS). This community service was attended by 20 people. In this training, the community was very enthusiastic and actively participated in the training. The community is able to quote signs and facts that require the help of Basic Life Support (BLS)
\end{abstract}

Keywords: Training, Basic Life Support, community 


\section{Pendahuluan}

Berhentinya sirkulasi beberapa detik sampai beberapa menit, akan menyebabkan asupan oksigen ke dalam otak terhenti, yang kemudian akan terjadi hipoksia otak yang mengakibatkan kemampuan koordinasi otak untuk menggerakkan organ otonom menjadi terganggu, seperti gerakan denyut jantung dan pernapasan. Penyelamatan ini akan sangat bermanfaat jika dilakukan sesegera mungkin dan sebaik mungkin. Lebih baik ditolong, walupun tidak sempurna daripada dibiarkan tanpa pertolongan. Pada saat henti napas, kandungan oksigen dalam darah masih tersedia sedikit, jantung masih mampu mensirkulasikannya ke dalam organ penting, terutama otak, jika pada situasi diberi bantuan pernapasan, kebutuhan jantung akan oksigen untuk metabolisme tersedia dan henti jantung dapat dicegah.

Kasus-kasus penyebab terjadinya henti jantung dan henti napas dapat terjadi kapan saja, dimana saja dan pada siapa saja. Contoh kasusnya antara lain adalah tenggelam, stroke, obstruksi jalan napas, menghirup asap, kercunan obat, tersengat listrik, tercekik, trauma, MCI (myocardialinfarction) atau gagal jantung, dan masih banyak lagi. Kondisi diatas, ditandai dengan tidak terabanya denyut nadi karotis dan tidak adanya gerakan napas dada.

Dalam American Heart Association Guideline for Cardio pulmonary Resuscitation and Emergency Cardiovascular Care 2010, AHA menekankan fokus bantuan hidup dasar pada Chainof Survival (Rantai Kelangsungan Hidup): Early recognition and activation. Melakukan pengenalan segera pada kondisi henti jantung dan mengaktivasi sistem respons gawat darurat (EMS/Emergency Medical Responses); Early CPR. Memberikan resusitasi jantung paru sedini mungkin; Early defibrillation. Melakukan defibrilasi sesegera mungkin. Pada tempat dan fasilitas umum, biasanya tersedia AED (Automated External Defibrillation); Effective advanced life support. Melakukan pemberian bantuan hidup lanjut dengan efektif; Integration of post-cardiac arrest care. Melakukan pemberian perawatan pasca henti jantung yang terintegrasi.

\section{Metode}

Metode yang digunakan adalah ceramah, diskusi, tanya jawab, dan simulasi cara melakukan Bantuan Hidup Dasar (BHD) dalam upaya pencegahan peningkatan kemampuan dan keterampilan dalam melakukan Bantuan Hidup Dasar (BHD). Pengabdian masyarakat ini dilaksanakan di Desa Karang Bayan Kecamatan Lingsar Kabupaten Lombok Barat. Keterkaitan antara kegiatan pengabdian masyarakat dengan Pelatihan Bantuan Hidup Dasar (BHD) pada Masyarakat merupakan kegiatan dalam rangka peningkatan kemampuan dan keterampilan dalam melakukan Bantuan Hidup Dasar (BHD).

Evaluasi pelaksanaan kegiatan dilakukan setelah pelaksanaan kegiatan. Tolak ukur yang dilakukan saat pengabdian masyarakat adalah peserta mampu melakukan atau mensimulasikan cara Bantuan Hidup Dasar (BHD). Cara Pelaksanaan evaluasi dengan mensimulasikan langkah atau cara melakukan Bantuan Hidup Dasar (BHD) dengan baik dan benar.

\section{Hasil}

Lokasi kegiatan sekitar $13 \mathrm{~km}$ dari lokasi kampus B Poltekkes Kemenkes Mataram. Lokasi pengabdian bertempat di Desa Karang Bayan Kecamatan Lingsar Kabupaten Lombok Barat. Pelaksanaan kegiatan ini dilakukan sebagai wujud perhatian tim pada lingkungan/masyarakat (Bina Lingkungan). 
Kegiatan pengabdian pada masyarakat ini diadakan pada hari Sabtu Tanggal 30 Agustus 2019 pukul 09.00 WITA sampai dengan selesi. Pengabdian masyarakat ini dihadiri oleh masyarakat sejumlah 20 Orang. Dalam kegiatan ini masyarakat sangat antusias dan aktif dalam mengikuti pelatihan.

Evaluasi dilakukan langsung setelah pelatihan yang dilakukan oleh tim dengan memberikan memberikan kesempatan kepada masyarakat untuk melakukan BHD dan mengevaluasi dengan lembar checklist.

\section{Kesimpulan}

Setelah dilaksanakan pelatihan BHD, masyarakat mampu menyebutkan tanda dan gejala seseorang yang membutuhkan pertolongan Bantuan Hidup Dasar (BHD) dan mampu melaksanakan cara pemberian pertolongan Bantuan Hidup Dasar (BHD).

\section{Ucapan Terima Kasih}

Pengabdi mengucapkan terima kasih kepada Poltekkes Kemenkes Mataram yang telah memberikan dana kegiatan pengabdian kepada masyarakat ini.

\section{Daftr Pustaka}

Berg, R. A., Hemphill, R., Abella, B. S., Aufderheide, T. P., Cave, D. M., Hazinski, M. F., . . Swor, R. A. (2010). Part 5: Adult basic life support. Circulation, 122(18 suppl 3), S685-S705.

Brennan, E., \& Terry, M. (2015). Adult basic life support and cardiopulmonary resuscitation quality: 2015 American Heart Association Guidelines Update for cardiopulmonary resuscitation and emergency cardiovascular care. Circulation, 132, S414-S435.

Edwin, N., Ahmad, N. S. B., Pek, P. P., Yap, S., \& Ong, M. E. H. (2017). The Pan-Asian
Resuscitation Outcomes Study (PAROS) clinical research network: what, where, why and how. Singapore medical journal, 58(7), 456.

Erpan, E. (2016). Gambaran Keterampilan Pemasangan Infus Pada Perawat Vokasional Dan Perawat Profesional Rumah Sakit PKU Muhammadiyah Di Wilayah Yogyakarta.

Gräsner, J.-T., \& Bossaert, L. (2013). Epidemiology and management of cardiac arrest: What registries are revealing. Best Practice \& Research Clinical Anaesthesiology, 27(3), 293306.

doi:https://doi.org/10.1016/j.bpa.2013.07.008 